\title{
The Effect of Work Demand, Role Conflict, and Role Ambiguity on Work-Family Conflict (Impact of Work From Home due to The Covid-19 Pandemic)
}

\author{
Farika Nikmah $^{1 *)}$, Titien Indrianti ${ }^{2}$, Joni Dwi Pribadi ${ }^{3}$ \\ ${ }^{1,2,3}$ Business Administration Department, State Polythechnic of Malang, \\ East Java Indonesia, 65141 \\ *) Corresponding author: farika.nikmah@polinema.ac.id
}

\begin{abstract}
Because of the Covid-19 pandemic, this research's background was to break the chain of virus spread, and the government requires physical distancing. Working from home, which causes many employees to work from home, creates conflicts for married female workers. The research objective is to examine and analyze the direct effect of job demands, role conflict, role ambiguity on work-family conflicts. Data were obtained through questionnaires and submitted online to 100 married women who work in universities in East Java, Indonesia, both public and private, and then the analysis was carried out using Partial Least Square (PLS). The results showed that all hypotheses were accepted, and the most dominant influence was role conflict on family-work conflicts. The conclusion is that married women experience many conflicts in carrying out their jobs because other demands must also be considered, namely the mother and wife's role.
\end{abstract}

Keywords: role ambiguity, role conflict, work demand, work-family conflict, work from home

\begin{abstract}
Abstrak
Latar belakang penelitian ini karena adanya pandemi Covid-19, dimana untuk memutus rantai penyebaran virus, pemerintah mewajibkan untuk physical distancing. Bekerja dari rumah yang menyebabkan banyak karyawan bekerja dari rumah justru menimbulkan konflik bagi pekerja perempuan yang sudah berkeluarga. Tujuan penelitian menguji dan menganalisis pengaruh langsung tuntutan pekerjaan, konflik peran, ambiguitas peran terhadap konflik keluarga pekerjaan. Data diperoleh melalui kuesioner dan disampaikan secara online kepada 100 wanita menikah yang bekerja di perguruan tinggi di Jawa Timur, Indonesia, baik negeri maupun swasta, kemudian analisis dilakukan dengan menggunakan Partial Least Square (PLS). Hasil penelitian menunjukkan bahwa semua hipotesis diterima, dan pengaruh yang paling dominan adalah konflik peran terhadap konflik keluarga. Kesimpulannya, bahwa wanita yang sudah menikah banyak mengalami konflik dalam menjalankan pekerjaannya, karena ada tuntutan lain yang juga harus diperhatikan yaitu peran sebagai ibu dan istri.
\end{abstract}

Kata kunci: ambiguitas peran, bekerja dari rumah, konflik keluarga, konflik peran, tuntutan pekerjaan. 


\section{Introduction}

Coronavirus affects all human life conditions, both the formal and informal ones. The effects cover the psychological and financial conditions (Holmes, 2020). Psychological aspects, such as stress, despair, and saturation, are the most common problems (Shepherd-Banigan, Bell, Basu, Booth-LaForce, \& Harris, 2016). As the smallest system in the community, the family is also influenced by this pandemic (Kotera, Ozaki, Miyatake, Tsunetoshi, Nishikawa, \& Tanimoto, 2020). If previously, a family could spend their weekend for recreation and relaxation, now they could not. All the members are forced to stay at home. The parents go to work in the morning to afternoon, but sometimes at night, and children go to school from morning to afternoon, now all those activities should be done at home. The first and second week of the stay at home activity was manageable since each of the family members spent their time together while doing their activity, but after that, are they fine? The answer to this question is probably different between one family and another one.

This research focuses on the family in which the wife or the mother is a career woman. The general opinion exists in surrounding that married woman, both the career woman or the housewife, who has children is supposed to be able to fulfill her husband and children necessities create double roles for the woman which frequently lead to a conflict between her working pressure and her role in her family (Greenhaus \& Beutell, 1985). Based on Choi and Kim (2012), many Koreans face the conflict between working pressure and family role. Several studies were also conducted in ASEAN countries, which showed similar results, in Malaysia (Zakaria \& Ismail, 2017), Singapore (Kim, 2001; Ahmad \& Skitmore, 2003). Another similar research done in Canada has the same result (Mansour \& Tremblay, 2016). Besides that, there is a phenomenon that during work from home is the changing time of splitting (Kotera et al., 2020). People generally finish their work in the office without having a requirement to bring it home, but now, all the work should be done at home. This is due to government policy to work from home as an effort to break the chain of spreading the Coronavirus. At the same time, all the family spends their time at home to do their own job, instead of having fun or having a holiday. Before the pandemic, when people are at home, it is time to do the housework and spend quality time with family, but now a house becomes the only place to do all the office work and housework. Does it create a conflict? Absolutely. There will be a complaint from the husband and children in which they feel of being neglected by the busy activity of the wife and mother; it seems that the mother and wife are at home, but she keeps on doing her office work (Dockery et al., 2014). While in normal life, if she is at home, she is only theirs. The work from home condition camouflages the situation, and she seems at home, but she is full of her duty from her office and, this condition also makes her feel guilty. There is a condition where for a husband and children, a woman should spend her total attention, feeling, and time for them, not only the physical existence. The early prediction is that work from home can be the solution for a career woman since she can spend all her time at home without going out for work, but the fact is that she cannot fulfill all the demands from her husband and children. As a permanent employee, some duties should be done and, at the same time, there is housework that also needs to be finished, so there will be difficulty in splitting the time. It seems that she has no time for herself because all the family members need her attention and, it ends up with a late working submission (Banerjee \& Rai, 2020). 
The situation is different from working in the office: the working hour set in eight hours as normal and the different situation happens when it is at home. The working hours feel like 24 hours without stopping and starting the problem. In Javanese tradition, married women are label as housewives, identical to women who are economically dependent on their husbands and only do household chores (Ida, 2001). In Indonesia, housewives have no obligation to work (Ford \& Parker, 2008). Research founding by Ida (2001), the role of women dwarfed in society, so the history of femininity in Indonesia is influenced by ancient Javanese culture, which usually mixes with Islamic norms to verify gender constructs weaken women's identity strongly. The Javanese population and most of the Indonesian population (about 90\%) are Muslim (Bennington \& Habir, 2003). However, it should be underlined that the implementation of Islamic culture in Indonesia is different according to the region (Ida, 2001). Women are allowed to work, but it is not an obligation because labor division between men and women in marriage is explicitly stated in the Quran, the holy book of Islam. In particular, the husband is the guardian of the women in the family and the family's main breadwinner. Javanese cultural values that prioritize mutual respect produce a wife who can help her husband work (Reeves, 2010). Although Javanese culture recognizes gender equality, several regulations made by the state favor men as the main workers.

The term mother is usually discussed in a biological term, which means that it clarifies the many choices of women's roles for their families. Ibuism can be a term that was to explain muliebrity thoughts in the Indonesian context, which originated from Javanese culture, which discusses women's role. Thus, according to Hinduism's principle, in everyday life, women must be responsible for managing and taking care of household matters (for example, cleaning the house, washing clothes, cooking) and taking care of everything, especially serving all the needs of children and her husband. The role of women is clearly described in the familiar Javanese term for ancient women's work: (1) cooking, women, must be responsible for preparing food and serving all the needs of their husbands and families; (2) makeup - women should be responsible for keeping the house clean and tidy; (3) childbirth - women must be responsible for childbirth, care and education (Hidayati, Zarlis, \& Absah, 2019). If previously, a career woman complained about having less time to stay at home, now as the pandemic's effect makes her do the work from home in which she has to finish her work at home seems still unable to solve the double roles conflict of a mother. A mother's role that makes her totally have to dedicate herself to her husband and children forces her to put aside other duty or activities, even the official duty. So, staying at home for a woman means that she has to, physically and psychologically, be exist and available for her husband and children. Thus, it can be implicitly concluded that it is not about a mother has to spend more time staying at home, but it is more about the mother has to play a great role in making all the family activities works well, and that is the main duty for a mother or wife. This condition is very problematic for a career woman since she must do both roles, as a mother or wife and as a career woman, at the same time, at the same place.

WFC is the effect of double roles had by a woman, being an employee and a wife or a mother, in which both roles cannot be compatible with each other in some parts (Greenhaus \& Beutell, 2015). It means that it is difficult to do those roles well, either in the office as a mother or wife or at home as an employee, especially if the woman has a high involvement in the office atmosphere (Apperson, 2002; Ezzedeen \& Ritchey, 2009). During the process, WFC's effect can be seen in two different perspectives: an individual and an organization. In the individual level, it can promote individual 
distress, psychological harm, and even influence on physical health (Frone, 2000); (Major, Quinton, \& McCoy, 2002). In the organization level, WFC is tightly bound with some problems such as low productivity (Konrad \& Mangel, 2000), low working and career satisfaction, and being absent (Erickson, Nichols, \& Ritter, 2000), late, less commitment in working, and the willingness to move (Parasuraman \& Greenhaus, 2002; Wang \& Lawler, 2004). The study that focuses on WFC in Indonesia is started to be developed (Nastiti, Fang, Indarti, \& Chen, 2016; Panorama \& Jdaitawi, 2011; Hidayati, Zarlis, \& Absah, 2019; Nurmayanti, Thoyib, Noermijati, \& Irawanto, 2014).

Most of the research uses the term work to family conflict $(\mathrm{W} \rightarrow \mathrm{FC})$, which refers to work activities that impact family conflict. Like today, the obligation to work from home due to Covid-19 where a mother has to stay at home doing her job. Based on previous research (Ahmad \& Ahmed, 2011), Malaysian women focus more on work demand than family demand. It was stated that a greater problem faced by women with children under five at home. Similar conditions occur in Hong Kong and Singapore, where women's traditional roles are very obedient to culture (Ahmad \& Ahmed, 2011).

The development of study related to Work-Family Conflict (WFC) has been done by several researchers, such as the research about WFC related to the role (Ryan, Ma, \& Ku, 2009), work demand, and turnover intention (Boyar, Maetz, Jr, Pearson, \& Keough, 2003; Asghar, Gull, Bashir, \& Akbar, 2018), work demand and job satisfaction (Boles, Howard, \& Donofrio, 2001; Rahman et al., 2018), and work demand and stress, exhaustion (Boyar et al., 2003). Those researches show that many researchers interested in studying the woman who has double roles have a responsibility both for her work and family.

Based on previous research, those work-family conflicts are caused by work demand, role conflict, and role ambiguity. The current research aims to determine the effect of work demand, role conflict, and role ambiguity on work-family conflicts, especially when an obligation to work from home caused the Covid-19 Pandemic.

\section{Methods}

\section{Participants}

This study's samples are married-female lecturers of public and private universities in East Java, Indonesia. The survey has done by spreading the questionnaire through Google form, in which the questions are closed-ended, to gather data and a fivepoint Likert scale to measure the variables of the research model. The scale items were evaluated from strongly agree (5) to strongly disagree (1). All the data collected is based on self-rated responses of participants. The data collection took place from April 2020 to May 2020. All the study participants were informed of the investigation aims and provided their verbal consent to participate in the survey. A self-report questionnaire was administered to 200 individuals, out of which 110 participated in the study. Only fully filled questionnaires were taken into consideration for further analysis. After the elimination of questionnaires with missing values, the final sample consisting of 100 participants was investigated in detail.

\section{Measurements}

Most of the statements used for developing the questionnaire were drawn from the literature on work-family conflict. All the items used are extracted from literature and different case studies on women's work-family conflict. To measure the direct relation 
of the independent variable work demand, the researcher used 2 items (Yang, Chao, Choi, \& Zou, 2000), role conflict and role ambiguity, each of them has 8 items and 6 items (Schuler \& Aldag, 1977). In contrast, in the dependent variables - work-family conflict- there are 5 items (Boles et al., 2001), with a five-point Likert rating scale was used to measure their responses. The scale ranged from five (strongly agree) to one (strongly disagree).

Table 1. Indicators and Items

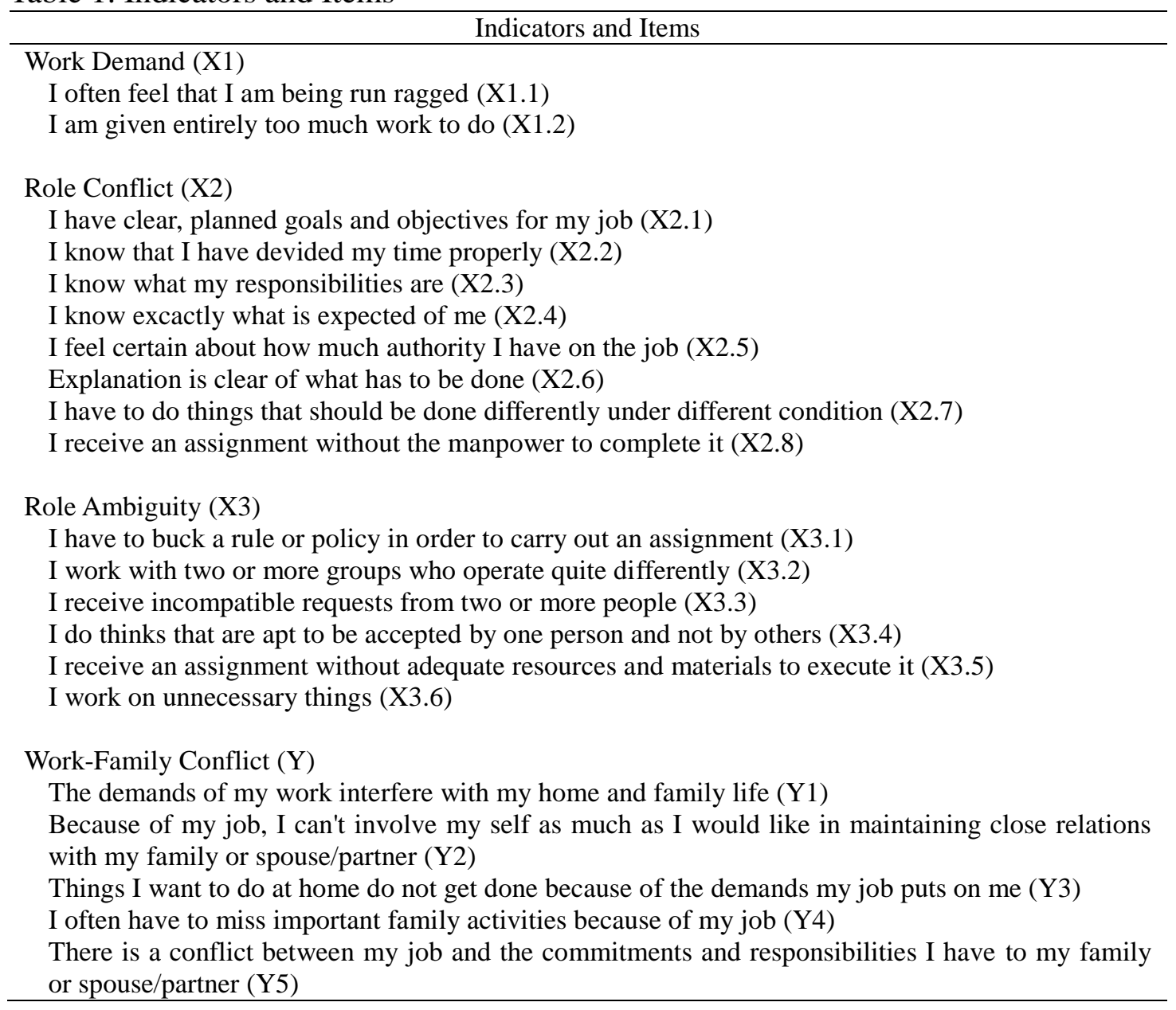

\section{Analysis}

Partial least square (PLS) was used to test the direct effect between exogenous variables (work demand, role conflict and role ambiguity), toward the endogen variable (work-family conflict). The first step was by drawing a path diagram (picture 1) that describes the relationship between the exogenous variables and endogen variables (structural model/ inner model) and the relationship among the exogenous variable and endogen variables toward each indicator (measurement model/ outer model). Second, the researcher did an assessment or estimation model in picture 1 by using the PLSSEM algorithm- partial regression model. Third, the researcher evaluated the structural model (outer model) in the PLS-SEM to know the constructor indicator's validity and reliability. Fourth, evaluation in the structural model (inner model) in some steps: collinearity testing, relation significance testing in the structural model and measure the $\mathrm{R}^{2}$ value. Here the conceptual framework and hypothesis: 
The following hypotheses were suggested based on the comprehensive literature review and information in accordance with table 1 :

H1. Work demand has a significant relationship with work-family conflict.

$\mathrm{H} 2$. Role conflict has a significant relationship with work-family conflict.

H3. Role ambiguity has a significant relationship with work-family conflict.

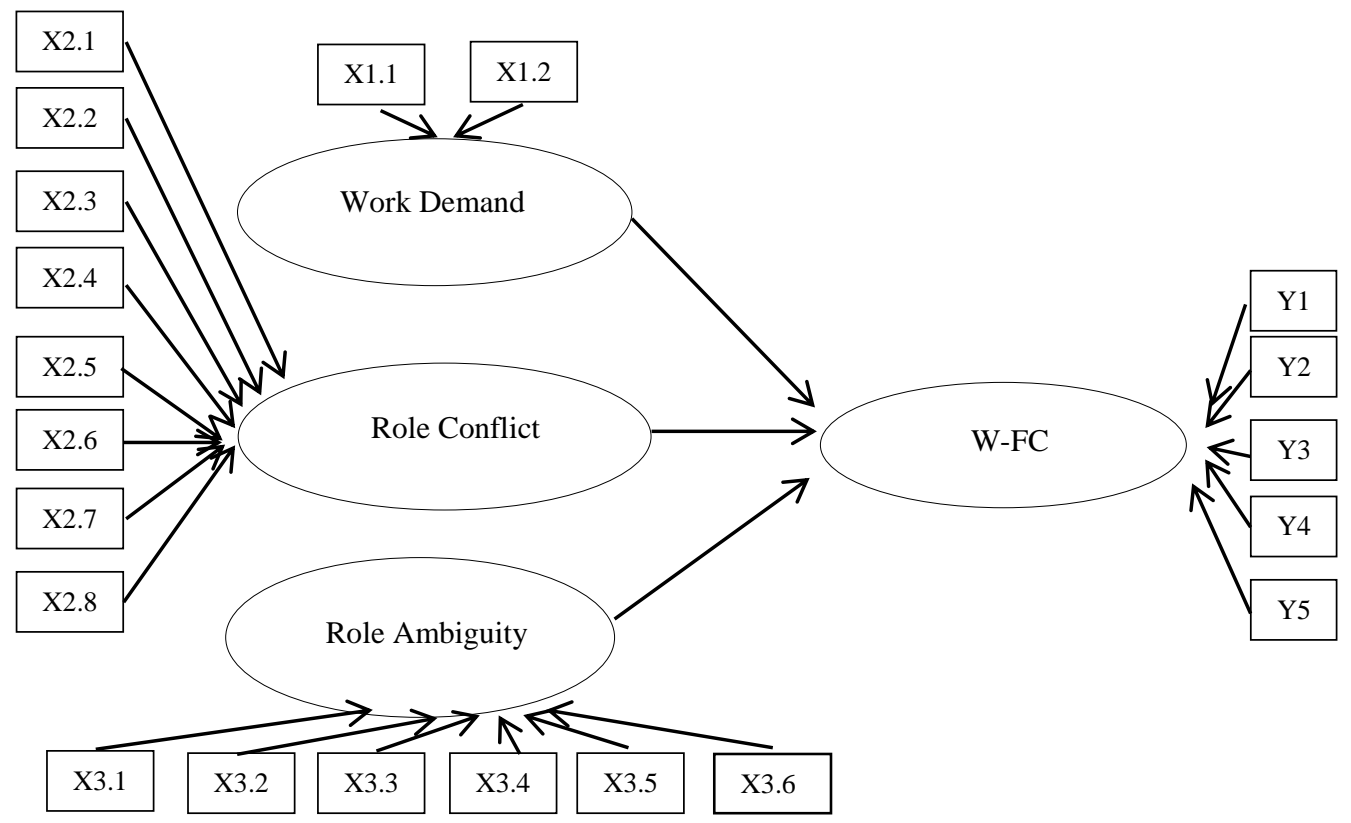

Figure 1. Conceptual framework and hypothesis

\section{Findings}

Hypothesis testing is got by doing the bootstrapping program, using the belief level of $95 \%$ so the limit of inaccuracy $\alpha=0,05$. Here the results:

The results showed that $35.5 \%$ of participants were between the ages of 30 and 35 , and $64.4 \%$ of the participants were between 35 and 40 years old. Only $2.1 \%$ of the participants were over 40 years old. Participants with less than 5 years of working experience constituted $34.5 \%$ of the analyzed sample, and $61.5 \%$ of participants had $6-$ 10 years of experience. Most of the respondents had a master's degree $79.1 \%$, the rest were holding a doctor degree $20.8 \%$. The public universities' participants are $64.7 \%$ and from the private universities are $35.3 \%$.

Table 2. Relation testing of variable and the item

\begin{tabular}{lrrrr}
\hline Variable & Mean & $\begin{array}{r}\text { Standard } \\
\text { deviation }\end{array}$ & t statistic & p values \\
\hline $\mathrm{X} 1.1 \rightarrow$ work demand & 0.139 & 0.216 & 0.692 & 0.049 \\
$\mathrm{X} 1.2 \rightarrow$ work demand & 0.442 & 0.181 & 0.739 & 0.006 \\
$\mathrm{X} 2.1 \rightarrow$ role conflict & 0.747 & 0.080 & 9.694 & 0.000 \\
$\mathrm{X} 2.2 \rightarrow$ role conflict & 0.827 & 0.056 & 15.267 & 0.000 \\
$\mathrm{X} 2.3 \rightarrow$ role conflict & 0.874 & 0.049 & 18.587 & 0.000 \\
$\mathrm{X} 2.4 \rightarrow$ role conflict & 0.766 & 0.071 & 11.195 & 0.000 \\
$\mathrm{X} 2.5 \rightarrow$ role conflict & 0.807 & 0.065 & 12.909 & 0.000 \\
$\mathrm{X} 2.6 \rightarrow$ role conflict & 0.674 & 0.082 & 8.535 & 0.000 \\
\hline
\end{tabular}




\begin{tabular}{lrrrr}
\hline Variable & Mean & $\begin{array}{r}\text { Standard } \\
\text { deviation }\end{array}$ & t statistic & p values \\
\hline X2.7 $\rightarrow$ role conflict & 0.857 & 0.049 & 18.223 & 0.000 \\
$X 2.8 \rightarrow$ role conflict & 0.776 & 0.076 & 10.613 & 0.000 \\
$X 3.1 \rightarrow$ role ambiguity & 0.626 & 0.185 & 4.279 & 0.000 \\
$X 3.2 \rightarrow$ role ambiguity & 0.521 & 0.188 & 3.475 & 0.001 \\
$X 3.3 \rightarrow$ role ambiguity & 0.621 & 0.163 & 4.915 & 0.000 \\
X3.4 $\rightarrow$ role ambiguity & 0.506 & 0.201 & 3.091 & 0.002 \\
$X 3.5 \rightarrow$ role ambiguity & 0.274 & 0.224 & 1.489 & 0.137 \\
X3.6 $\rightarrow$ role ambiguity & 0.416 & 0.220 & 2.369 & 0.018 \\
Y1 $\rightarrow$ WFC & 0.788 & 0.044 & 17.926 & 0.000 \\
Y2 $\rightarrow$ WFC & 0.902 & 0.026 & 34.267 & 0.000 \\
Y3 $\rightarrow$ WFC & 0.904 & 0.028 & 31.989 & 0.000 \\
Y4 $\rightarrow$ WFC & 0.799 & 0.052 & 15.527 & 0.000 \\
Y5 $\rightarrow$ WFC & 0.872 & 0.030 & 29.567 & 0.000 \\
\hline
\end{tabular}

Before answering the hypothesis, testing the relationship between items and indicators is carried out. The results showed that the items supported the indicators (table 1). It appears that the value of each item that supports the work demand indicator has $t$-stat value above the $t$ table and a $p$-value less than 0.05 and is significant, likewise with every item that supports role conflict and role ambiguity.

Based on the testing, all hypotheses are accepted. Hypothesis 1 is stated to be accepted, that there is a relationship between work demand and WFC. In hypothesis 1, the item "I am given entirely too much work to do" has the highest level of significance. The same is the case with hypothesis 2 that there is a relationship between role conflict against WFC. The biggest conflict faced by career women with their families is role conflict, which means answering hypothesis 2 of this study. Hypothesis 3 shows the relationship between work ambiguity on WFC. Whereas for hypothesis 3, role ambiguity gives a positive value but does not significantly impact the WFC. All stated accepted that the $t$ stat value is more than the $t$ table and the $p$-value is less than 0.05 .

Table 3. Test on the relationship between the exogenous variable and endogen variable

\begin{tabular}{lrrrr}
\hline Variable & Mean & $\begin{array}{r}\text { Standard } \\
\text { deviation }\end{array}$ & t statistic & p values \\
\hline Work demand $\rightarrow$ WFC & -0.233 & 0.067 & 3.233 & 0.001 \\
Role conflict $\rightarrow$ WFC & 0.526 & 0.067 & 8.305 & 0.000 \\
Role ambiguity $\rightarrow$ WFC & -0.266 & 0.082 & 2.528 & 0.012 \\
\hline
\end{tabular}

\section{Discussions}

The results showed that respondents who had toddlers mostly answered the questionnaire's questions faced serious problems with the work from home policy. Fearing that someone else was at home and contracting the virus, her house assistant was no longer employed, and he took care of all family matters alone. The COVID-19 pandemic marks the transition from offline to online-based and a physical distancing policy, where all work from home and learn from home. Before the pandemic, husbands, wives, and children could share their time equally: spending time with friends at work and at school. Now all activities are carried out at home that can affect psychologically, especially for a mother who is also working. 
Career women frequently have a problem in balancing their roles. Being a working woman or a housewife is a choice. When a woman chooses to be a working woman, it is not only caused by the financial problem, and it can also be caused by the necessity to fulfill personal needs such as satisfaction, comfort, and ego. So, it is important to have some help from other people to finish the housework such as cleaning and taking care of children. A career woman is still a human being, has a limit in mind and energy. The result shows that, it is important for a woman who chooses to be a career woman to know and be prepared with all the risk to play both housewife and a career woman. The basic thing to be known is to make a priority: decide which one should be put as the top priority and order them to the less by considering the importance of each one. Having priority can reduce conflict and automatically reduce physical and psychological problems such as stress. The double roles will always cause the problem in the family, so instead of dismissing it, reducing is the best choice by making an agreement between husband and wife. The problem will be less when the children are grown up or when the family sets up other agreement.

This is in line with research conducted by (Boyar et al., 2003; Asghar et al., 2018), which states that they often have to continue office work at home. Another response stated that work demand causes a conflict in the family. The problem is that there is no energy after finishing work. It's time to go home, so they do not have any enthusiasm in spending time with the family, similar to research conducted by (Frone, 2000), that female employees often feel tired and tend to be stressed.

This study found that respondents said that work from home could be caused tiredness. Not going to work does not mean that it reduces tiredness. On the other way around, work from home makes the woman has no break since she has to keep teaching online while doing all the housework, and there is an additional task, helping the children with their online class. It makes her exhausted. While in the Javanese philosophy, a mother is the last one to sleep for she has to make sure that all necessity of the family is fulfilled and after that, she has to prepare their needs for tomorrow. This philosophy becomes the boundary for a married woman to dedicate her time to family.

Being able to meet the demands of a job, doing all tasks well is an obligation that must be fulfilled. The results of this study indicate that professionalism is needed in carrying out a job while also having to take care of the family, as research conducted by (Rahman et al., 2018) and states that female workers who are married have multiple roles, have responsibilities both for work and for their families (Boyar et al., 2003). Especially when working from home, there is a role conflict. On the one hand, they have to keep working even at home, but on the other hand, there are high demands to keep taking care of their family, which means that office work is neglected.

As a lecturer, he can creatively manage his class without instruction. There is actually no problem with adequate IT equipment with online classes that must be managed. There are already teaching tools such as RPS, modules, and textbooks, which can help students communicate. The current study results are not in accordance with the research conducted by (Schuler \& Aldag, 2017), where the respondents were bank workers who worked with full pressure and control from the leadership, while the lecturers worked creatively without supervision from their superiors. This research is still limited to homogeneous respondents. Lecturers with job characteristics that are not the same as other types of work, such as bank workers, factories, or employers, cannot provide valid generalizations about the problems of job demands, role conflicts, and role ambiguities that affect the WFC. 


\section{Conclusion and Recommendation}

\section{Conclusion}

Based on research, working as a lecturer for married women also creates obstacles due to government regulations to work from home to break the chain of spreading the Coronavirus. Role conflict has a dominant influence on the WFC, rather than job demand and role ambiguity. Role conflict is closely related to a wife's obligation to take care of the family. However, due to various considerations, a wife also has to earn a living so that there are consequences and commitment between husband and wife to minimize family conflicts.

\section{Recommendation}

Based on this research, suggestions that can be given to women who may be working and married can consider good communication about the share tasks with their husbands, commitment with their spouses when their wives are also earning a living, and having permission from their partners. For further research, requests that a wider scope of the research be carried out at different times with different research subjects as seen from the side of husbands or married men.

\section{References}

Ahmad, M. S., \& Ahmed, J. (2011). Working women work-life conflict. Business Strategy Series, 12(6), 289-302. Doi: 10.46422/pjgs.v19i0.83.

Ahmad, S., \& Skitmore, M. (2003). Work-family conflict: a survey of Singaporean workers. Singapore Management Review, 25(1), 35-52.

Apperson, M. (2002). Women managers and the experience of work-family conflict. American Journal of Undergraduate Research, 1(3), 9-16. Doi: 10.33697/ajur.2002.020.

Asghar, M., Gull, N., Bashir, M., \& Akbar, M. (2018). The impact of work-family conflict on turnover intentions: the moderating role of perceived family supportive supervisor behavior. Journal of Hotel \& Business Management, 7(1), 1-11. Doi: 10.4172/2169-0286.1000178.

Banerjee, D., \& Rai, M. (2020). Social isolation in covid-19: the impact loneliness. International Journal of Social Psychiatry, 66(6), 525-527. Doi: https://doi.org/10.1177\%2F0020764020922269.

Bennington, L., \& Habir, A. (2003). Human resource management in Indonesia. Human Resource Management Review, 13(3), 373-392. Doi: 10.1016/S10534822(03)00041-X.

Boles, J. S., Howard, W., \& Donofrio, H. (2001). An investigation into the interrelationships of work-family conflict, family-work conflict and work satisfaction. Journal of Managerial Issues, 13(3), 376-390. Retrieved from: https://www.researchgate.net/publication/265511033.

Boyar, S. L., Maetz, Jr, C., Pearson, A., \& Keough, S. (2003). Work-family conflict: a model of linkages between work and family domain variables and turnover intentions. Journal of Managerial Issues, 15(2), 175-190. Retrieved from: https://www.jstor.org/stable/40604424.

Choi, H. J., \& Kim, Y. (2012). Work-family conflict, work-family facilitation, and job outcomes in the Korean hotel industry. International Journal of Contemporary 
of Hospitality Management, 24(7), 1011-1028. Doi: https://doi.org/10.1108/0959-6111.211258892.

Erickson, R. J., Nichols, L., \& Ritter, C. (2000). Family influences on absenteeism: testing an expanded process model. Journal of Vocational Behavior, 57(2), 246272.

Ezzedeen, S.R., \& Ritchey, K.G. (2009). Career advancement and family balance strategies of executive women. Gender in Management, 24(6), 388-411. Doi: 10.1108/17542410910980388.

Ford, M., \& Parker, L. (2008). Women and Work in Indonesia. New York: Routledge.

Frone, M. R. (2000). Interpersonal conflict at work and psychological outcomes: testing a model among young workers. Journal of Occupational Health Psychology, 5(2), 246-255. Doi: https://doi.org/10.1037/1076-8998.5.2.246.

Greenhaus, J. H., \& Beutell, N. (2015). Sources of conflict between work and family roles. Academy of Management Review, 10(1), 76-88. Doi: 10.2307/258214.

Greenhaus, J., \& Buetell, N. J. (1985). Source of conflict between work and family roles. The Academy of Management Review, 10(1): 76-88. Doi: 10.2307/258214

Hidayati, N., Zarlis, M., \& Absah, Y. (2019). Effect of work-family conflict on commitment organization through work stress with religiosityas a moderating variable in health workers of Latersia Binjai Hospital. International Journal of Research and Review, 6(5), 167-187. Doi: https://doi.org/10.1006/jvbe.2000.1730.

Holmes, E.A., et al. (2020). Multidisciplinary research priorities for the Covid-19 pandemic: a call for action for mental health science. Postion Paper, 7(6), 547560. Doi: https://doi.org/10.1016/S2215-0366(20)30168-1.

Ida, R. (2001). The construction of gender identity in Indonesia: between cultural norms, economic implications and state formation. Masyarakat, Kebudayaan dan Politik, 14(1), 21-34. Retrieved from: https://journal.unair.ac.id.

Kim, J.L., \& Ling, S.C. (2001), Work-family conflict of women entrepreneurs in Singapore. Women in Management Review, 16(5), 204-221. Doi: https://doi.org/10.1108/09649420110395692.

Konrad, A. M., \& Mangel, R. (2000). The impact of work-life programs on firm productivity. Strategic Management Journal, 21(12), 1225-1237. Doi: https://doi.org/10.1002/1097-0266(200012)21:12<1225.

Kotera, Y., Ozaki, H., Miyatake, H., Tsunetoshi, C., Nishikawa, Y., \& Tanimoto, T. (2020). Mental halth of medical workers in Japan during Covid-19: relationship with loneliness, hope and self-compassion. International Journal of Environmental Research and Public Health, Doi: 10.21203/rs.3.rs-91467/v1.

Major, B., Quinton, W., \& McCoy, S. (2002). Antecedent and consequences of attributions to descrimination: theoritical and empirical advances. Advances in Experimental Social Psychology, 34, 251-330. Doi: https://doi.org/00652601/02.

Mansour, S., \& Tremblay, D.-G. (2016). Work-family conflict/family-work conflict, job stress, burnout and intention to leave in the hotel industry in Quebec (Canada): moderating role of need for family friendly practices as "resource passageways". The International Journal of Human Resource Management, 29(16), 1-33. Doi: https://doi.org/10.1080/09585192.2016.1239216.

Nastiti, T., Fang, M., Indarti , N., \& Chen, C.-H. (2016). Elucidating the work-family conflict among Indonesian lecturers in the period of education reform . Int. J. 
Management and Enterprise Development. 15(1), 24-42. Doi: 10.1504/IJMED.2016.075873.

Nurmayanti, S., Thoyib, A., Noermijati, \& Irawanto, D. (2014). Work family conflict: a review of female teachers in Indonesia. International Journal of Psychological Studies, 6(4), 134-142. Doi: http://dx.doi.org/10.5539/ijps.v6n4p134.

Panorama, M., \& Jdaitawi, M. (2011). Relationship between emotional intelligence and work-family conflict of University Staff in Indonesia. Proceeding of the International Conference on. Putrajaya: ISBN 978-983-42366-5-6.

Parasuraman, S., \& Greenhaus, J. (2002). Toward reducing some critical gaps in workfamily research. Human Resource Management Review, 12(3), 299-312. Doi: 10.1016/S1053-4822(02)00062-1.

Rahman, M.M., Ali, N.A., Mansor, Z.D., Jantan, A.H., Adedeji, B., Hosen, S., \& Alam, M.K (2018). Work-family conflict and job satisfaction: the moderating effects of gender. Academy of Strategic Management Journal, 17(5), 1-6.Doi: https://doi.org/10.18488/journal.1.2018.812.1157.1169.

Ryan, B., Ma, J., \& Ku, M. (2009). Role conflict, role ambiguity and work-family conflict among University Foodservice Managers. International CHRIE Conference-Refereed Track. Oklahoma.

Schuler, R. S., \& Aldag, R. (2017). Role conflict and ambiguity: a scale analysis. Organizational Behavior and Human Performance, 20(1), 111-128. Doi: https://doi.org/10.1016/0030-5073(77)90047-2.

Schuler, R. S., Aldag, R. J., \& Brief, A. P. (1977). Role conflict and ambiguity: a scale analysis. Organizational Behavior \& Human Performance, 20(1), 111-128. Doi: https://doi.org/10.1016/0030-5073(77)90047-2.

Shepherd-Banigan, M., Bell, J.F., Booth-LaForce, C., \& Harris, J.R. (2016). Symptoms among employed women with young children. International Journal of Behavioral Medicine, 23(1), 102-111. Doi: 10.1007/s12529-015-9482-2.

Wang, P., \& Lawler, J. (2004). Work-family conflict and job withdrawal intentions: the moderating effect of cultural differences. International Journal of Stress Management, 11(4), 392-412. https://doi.org/10.1037/1072-5245.11.4.392.

Yang, N., Chen, C.C., Choi, J., \& Zou, Y. (2000). Sources of work-family conflict: a Sino-U.S. of comparison of the effects of work and family demands. Academy of Management Journal, 43(1), 113-123. Doi: 10.2307/1556390.

Zakaria, N., \& Ismil, Z. (2017). The qonsequences of work-family conflict and the importance of social supports to reduce work-family conflict among amployees. Malaysian Journal of Social Sciences and Humanities (MJSSH), 2(2), 24-29. DOI: https://doi.org/10.47405/mjssh.v2i2.41. 